\title{
Production of perovskite catalysts on ceramic monoliths with nanoparticles for dual fuel system automobiles
}

\author{
${ }^{1 *}$ A. Khanfekr; ${ }^{1}$ K. Arzani; ${ }^{2}$ A. Nemati; ${ }^{3}$ M. Hosseini \\ ${ }^{1}$ Department of Metallurgy and Materials Engineering, Science and Research Branch, Islamic Azad University, \\ Tehran, Iran \\ ${ }^{2}$ Department of Metallurgy and Materials Engineering, Sharif University of Technology, Tehran, Iran \\ ${ }^{3}$ Science and Engineering research of Sapco Company, Iran Khodro Company, Tehran, Iran \\ Received 6 September 2008; $\quad$ revised 15 October 2008; $\quad$ accepted 25 November 2008; $\quad$ available online 10 December 2008
}

\begin{abstract}
Lanthanum, Cerium)(Iron, Manganese, Cobalt, Palladium)(Oxygen) ${ }_{3}$ - Perovskite catalyst was prepared by the citrate route and deposited on ceramic monoliths via dip coating procedure. The catalyst was applied on a car with XU7 motors and the amount of emission was monitored with vehicle emission test systems in Sapco company. The results were compared with the imported catalyst with noble metals such as palladium, platinum and rhodium by Iran Khodro company based on the Euro III standards. The catalysts were characterized by specific surface area measurements, scanning electron microscopy, X-ray diffraction, line scan and map. In the results, obtained in the home made sample, the amount of carbon monoxide, nitrogen oxides and hydrocarbons were lower than imported catalyst with Iran Khodro company with nobel metals. The illustration shows nano particles size on coat. The microstructure evaluation showed that the improved properties can be related to the existence of nano particles on coating.
\end{abstract}

Key words: Air pollution, carbon monoxide, nitrogen oxides, hydrocarbons, emissions, $X$-ray diffraction, line scan

\section{INTRODUCTION}

One of the main sources of air pollution in large cities is automotive exhaust gas emissions. Therefore, catalytic converters have been applied for exhaust gas treatment since the 1970s. Conventional three-way automotive exhaust catalysts contain precious metals palladium $(\mathrm{Pd})$, platinum $(\mathrm{Pt})$ and rhodium $(\mathrm{Rh})$ for treatment of pollutants such as carbon monoxide (CO), unburned hydrocarbons (HC) and nitrogen oxides (NOx), (Heck and Farrauto, 1995). One of the reasons of deterioration of these catalysts is considered to be due to the decrease in active surface area of precious metals caused by grain growth in high temperature redox (reduction-oxidation) fluctuations of the exhaust gas. To compensate for this deterioration, conventional catalysts are loaded with excess amounts of precious metals (Nishihata et al., 2005). The increasing prices of noble metals such as Pt, $\mathrm{Rh}$ and Pd driven partly by the large demand of the automotive industry motivates the investigation of 凶*Corresponding Author Email: arsia_khan@yahoo.com Tel: +98912 194 8661, Fax: +9821 88692396 material concepts to reduce the precious metal content in automotive catalysts (Mondragon Rodriguez et al., 2008). Perovskite-type oxides have general formula as $\mathrm{ABO}_{3}$ in which $\mathrm{A}$ is a rare earth or alkaline earth metal and $B$ is a transition metal and these oxides are typically $p$-type semiconductors. Their composition can be varied in a wide range by partial substitution of lower valent cation in A or B site yielding additional mobile anion vacancies. Their mixed conductivity by both ion and electron migration and their high nonstoichiometric composition have been resulted from the basis of the applications of this group of materials in these areas such as electrochemistry (Kharton et al., 1999; Cheng et al., 2005) catalysis (Leontiou et al., 2003; Tao and Irvine, 2004; Liu et al., 2007) solid oxide fuel cells (Skinner, 2001; Uhlenbruck and Tietz, 2004) oxygen separation membranes (Takamura et al., 2004) chemical sensors for the detection of humidity (Holc et al., 1995) alcohol (Kong and Shen, 1996) and gases such as oxygen 
(Lukaszewicz et al., 1990), hydrocarbon (Brosha et al., 2000) and nitric oxide (Traversa et al., 1995). Earlier studies reported on perovskite oxide $\mathrm{LaCo}_{\mathrm{x}} \mathrm{Fe}_{1^{\prime \prime} \mathrm{O}} \mathrm{O}_{3}$ mainly involved methane oxidation catalysis (Szabo et al., 2003; Royer et al., 2004; Royer et al., 2005a, 2005b; Goldwasser et al., 2005). Incorporation of small amounts of precious metals into a perovskite structure can prevent their sintering, reduce losses due to volatilization at high operating temperatures and avoid reactions with the support that show the catalyst deactivation. Recent attention has been concentrated on the use of palladium based catalyst for TWC (threeway catalyst) formulation. Pd is well known to have a good resistance to thermal sintering, lower price than $\mathrm{Pt}$ and $\mathrm{Rh}$ and also have a good activity for oxidation of CO and hydrocarbons (Rainer et al., 1997; Beck et al., 1997; Van Yperen et al., 1998).

The $\mathrm{LaFe}_{x} \mathrm{Co}_{(1 " x)} \mathrm{O}_{3}$ perovskite with $\mathrm{ABO}_{3}$ type structure is formed with La-atoms at the A-site coordinated with 12 oxygen and with iron (Fe) and cobalt (Co) at the B-site coordinated with six oxygen atoms. The $\mathrm{LaFeO}_{3}$ is orthorhombic and the $\mathrm{LaCoO}_{3}$ is rhombohedral (Mondragon Rodriguez et al., 2008). $\mathrm{LaCoO}_{3}$ is particularly attractive because it is one of the most reducible ABO3-type perovskites (Nakamura et al., 1979) and displays a rich phase behavior under reducing conditions (Hansteen et al., 1998; Huang et al., 2005) which can be significantly influenced on addition of a noble metal such as Pd, Pt and Rh (Engelmann-Pirez et al., 2005; Cimino et al., 2006). The tolerance factor $(t)=(r \mathrm{~A}+r \mathrm{O}) / \sqrt{2} \times(r \mathrm{~B}+r \mathrm{O})$ is one requirement to form a perovskite structure and must lie between $0.8<t<1.0 .2$. Due to this tolerance wide, variety of elements can be combined without change in the original structure. Precious metals such as Pd, $\mathrm{Pt}$, Rh can also be incorporated into the crystal lattice. In the present study, the ( $\mathrm{La}-\mathrm{Ce})(\mathrm{Fe}, \mathrm{Mn}, \mathrm{Co}, \mathrm{Pd}) \mathrm{O}_{3}-$ perovskites coating on ceramic monoliths were prepared by a dip coating procedure.

\section{MATERIALS AND METHODS}

Preparation of catalysts with ceramic monoliths

(La-Ce)(Fe, Mn, Co, Pd) $\mathrm{O}_{3}$-Perovskite catalyst was prepared by the citrate method. The following materials were used in appropriate quantities and dissolved in distilled water $\mathrm{Al}(\mathrm{OH})_{3}$ (Merck), $\mathrm{La}\left(\mathrm{NO}_{3}\right)_{3} \cdot 6 \mathrm{H}_{2} \mathrm{O}$ (Merck), $\mathrm{Mn}\left(\mathrm{NO}_{3}\right)_{2} \cdot 4 \mathrm{H}_{2} \mathrm{O}$ (Merck), $\mathrm{Ce}\left(\mathrm{NO}_{3}\right)_{3} \cdot 6 \mathrm{H}_{2} \mathrm{O}$ (Merck), $\mathrm{Co}\left(\mathrm{NO}_{3}\right)_{2} \cdot 6 \mathrm{H}_{2} \mathrm{O}$ (Merck), $\mathrm{Pd}\left(\mathrm{NO}_{3}\right)_{2} \cdot \mathrm{xH}_{2} \mathrm{O}$ (Merck) and $\mathrm{FeCl}_{2}$ (Merck). Citric acid monohydrate (Merck, 99.5 \%) were used as starting materials. Aqueous solution with cation ratio La: (Fe,Co,Ce,Pd) of 1: 3, 3.5, 0.4, 10.28 was prepared and dissolved in $1.50 \mathrm{~L}$ distilled water. The citric acid was added in $10 \mathrm{wt} \%$ excess over the stoichiometric quantity (14.01 g of $\mathrm{C}_{6} \mathrm{H}_{8} \mathrm{O}_{7} \cdot \mathrm{H}_{2} \mathrm{O}$ ) to insure complete complexation of the metal ions. Then, solution was stirred for $1 \mathrm{~h}$. The $\mathrm{pH}$ was regulated by adding hydrochloric acid $(\mathrm{HCl})$ and was reduced from 6.6 to 3.2 to reach best suspension. Materials were coated on two ceramic monoliths that made with cordierite phase $\mathrm{Mg}_{2} \mathrm{Al}_{4} \mathrm{Si}_{5} \mathrm{O}_{18}$ with cylinder length $(5 \mathrm{~cm})$, internal diameters $(8 \mathrm{~cm})$, external diameter $(12 \mathrm{~cm})$, wall thickness $(0.9 \mathrm{~mm})$ and geometric specific surface 23.555 q.m/gr. Both monoliths were dipped in the resulting solution and then were heating at $407 \mathrm{~K}$ $\left(134^{\circ} \mathrm{C}\right)$. The precursor was finally calcined in air at $760^{\circ} \mathrm{C}$ for $3 \mathrm{~h}$ to obtain the perovskite oxides.

\section{Dip coating technique}

The dip coating technique was applied as follows: The monolith was dipped and withdrawn in slurry at constant speed (12 cycles/min) for $30 \mathrm{~min}$. The monolith was hung and kept in the channels, direction perpendicular to the surface of the slurry during the whole dipping and withdrawing processes. Each dipping was followed by the removal of the excess of slurry by dry air and a subsequent heating at $407 \mathrm{~K}$ $\left(134^{\circ} \mathrm{C}\right)$ for $30 \mathrm{~min}$. The coating and heating procedures were repeated several times until the desired loading obtained few microns. Finally, the ceramic monoliths were calcined at $1033 \mathrm{~K}\left(760^{\circ} \mathrm{C}\right)$ for $3 \mathrm{~h}$.

\section{Canning and catalytic testing}

The catalyst canning was conducted in Tarabgin company Mat at Mashhad-IranKhodro factory and then fixed under $\mathrm{Rd}$ car in Sapco-Irankhodro workshop for the vehicle emission test systems (AVL).

\section{Catalyst characterization}

Phase identification of the fresh catalysts was carried out by X-ray diffractometry using a computerized SEIFERT/PTS 3003 X-ray diffractometer (Cu Ka radiation, $\lambda 1.54 \mathrm{~A}^{\circ}$ by Ni filter).

Diffractograms were recorded with a step scan of 0.1 for $2 \theta$ between $0^{\circ}$ and $80^{\circ}$. Scanning electron microscopy (SEM), line scan and map were performed by a Vega $2 \mathrm{XMU} /$ Tescan instrument to investigate 
the crystal size and morphology, as well as the elemental composition of the catalysts.

\section{RESULTS AND DISCUSSION}

\section{Emission percentage}

Table 1 and 2 show the emission percentage of prepared catalyst and Iran Khodro company's catalyst with Euro III standards and with gas fuel and gasoline fuel, respectively.

The data indicated that ( $\mathrm{La}-\mathrm{Ce})(\mathrm{Fe}, \mathrm{Co}, \mathrm{Pd}) \mathrm{O}_{3}$ Perovskite catalyst had lower emission when gas fuels (methane combustion), reduced CO, HC and NOx were more than Iran Khodro imported catalysts. The results indicated that when the gasoline fuels were applied, the data was approximately the same.

\section{$X$-ray diffraction $(X R D)$}

The diffractograms of ( $\mathrm{La}-\mathrm{Ce})(\mathrm{Fe}, \mathrm{Co}, \mathrm{Pd}) \mathrm{O}_{3}$ coated on ceramic monoliths are displayed in Fig. 1. $\mathrm{X}$-ray diffraction shows the following phases: [((Mg, $\left.\left.\mathrm{Fe})_{2} \mathrm{Al}_{4} \mathrm{Si}_{5} \mathrm{O}_{18}\right)\right],\left(\mathrm{LaCo}_{0.4} \mathrm{Fe}_{0.6} \mathrm{O}_{3}\right),\left(\mathrm{La}_{2} \mathrm{PdO}_{4}\right)$, $\left(\mathrm{Ce}_{3} \mathrm{Pd}_{20} \mathrm{Si}_{6}\right)$ and $\left[\left(\left(\mathrm{Mg}_{0.86} \mathrm{Fe}_{0.14}\right)\left(\mathrm{Ce}_{0.5} \mathrm{La}_{0.5}\right)_{2}\left(\mathrm{CO}_{3}\right)_{4}\right)\right]$.

From the results, one can concluded that the crystal structure of perovskite-type can be obtained in all concentration ranges of $\mathrm{Co}$ and $\mathrm{Co}$ can substitute for
Fe limitlessly to form $\mathrm{LaCo}_{\mathrm{x}} \mathrm{Fe}_{1 " \mathrm{x}} \mathrm{O}_{3}$ solid solution. As it is known, an ionic radii rule is required to form perovskite structure, i.e. the so-called tolerance factor $(f t)$ defined by the equation:

$\mathrm{ft}=(r \mathrm{~A}+r \mathrm{O}) / 2(r \mathrm{~B}+r \mathrm{O})$

Where, $0.75<f \mathrm{t}<1.0 . r \mathrm{~A}, r \mathrm{~B}$ and $r \mathrm{O}$ are the ionic radii of $\mathrm{A}, \mathrm{B}$ and the oxygen anion, respectively. Because the ionic radii of $\mathrm{CO}^{2+}$ and $\mathrm{Fe}^{3+}$ are 0.074 and $0.064 \mathrm{~nm}$, respectively (Zhuyi Wang et al., 2008), this slight difference makes the perovskite structure to be maintained within tolerance factor.

Since the microstructure of the substituted perovskite contains no more Pd-particles, it can be postulated that the reoxidation treatment of the reduced $\mathrm{LaFe}_{0.65} \mathrm{Co}_{0.3} \mathrm{Pd}_{0.05} \mathrm{O}_{3}$ causes the reversible incorporation of Pd ions into the crystal structure of the perovskite (Mondragon Rodriguez et al., 2008).

\section{Scanning electron microscopy (SEM)}

The SEM micrograph (Figs. 2 and 3) of (La$\mathrm{Ce})(\mathrm{Fe}, \mathrm{Co}, \mathrm{Pd}) \mathrm{O}_{3}$ shows that surface of the ceramic monoliths were completely covered on the surface of coat. Size of the pores were uniform $(1-5 \mu \mathrm{m})$ and the size of particles were between 5 to $90 \mathrm{~nm}$. The SEM micrograph, map (Fig. 4.) and line scan (Figs. 5 and 6)

Table 1: The emission percentage of prepared catalyst and Iran Khodro Company catalyst with gas fuel ( $\lambda$ =Stoichiometric pointair/fuel ratio)

\begin{tabular}{lcccc}
\hline Parameters & $\begin{array}{c}\text { Emission percentage of } \\
\text { catalyst after 15 min }\end{array}$ & $\begin{array}{c}\text { Emission percentage of } \\
\text { catalyst at first }\end{array}$ & $\begin{array}{c}\text { Emission percentage of Iran } \\
\text { Khodro catalyst after 15 min }\end{array}$ & $\begin{array}{c}\text { Emission percentage of } \\
\text { Iran Khodro catalyst at first }\end{array}$ \\
\hline$\lambda$ & 1.019 & 1.025 & 1.024 & 1.039 \\
$\mathrm{CO}$ & 0.180 & 0.340 & 0.360 & 0.510 \\
$\mathrm{CO}_{2}$ & 12.60 & 12.20 & 11.90 & 11.80 \\
$\mathrm{O}_{2}$ & 0.550 & 0.710 & 0.820 & 0.990 \\
$\mathrm{HC}$ & 52 & 63 & 64 & 71 \\
$\mathrm{NOx}$ & 19 & 26 & 22 & 29 \\
\hline
\end{tabular}

Table 2: The emission percentage of prepared catalyst and Iran Khodro Company catalyst with gasoline fuel $(\lambda=$ Stoichiometric point-air/fuel ratio)

\begin{tabular}{lcccc}
\hline Parameters & $\begin{array}{c}\text { Emission percentage of } \\
\text { catalyst after 15 min }\end{array}$ & $\begin{array}{c}\text { Emission percentage of } \\
\text { catalyst at first }\end{array}$ & $\begin{array}{c}\text { Emission percentage of Iran } \\
\text { Khodro catalyst after 15 min }\end{array}$ & $\begin{array}{c}\text { Emission percentage of Iran } \\
\text { Khodro catalyst at first }\end{array}$ \\
\hline$\lambda$ & 1.015 & 1.016 & 1.015 & 1.016 \\
$\mathrm{CO}$ & 0.430 & 0.540 & 0.450 & 0.560 \\
$\mathrm{CO}_{2}$ & 15.40 & 15.10 & 15.40 & 15.10 \\
$\mathrm{O}_{2}$ & 0.530 & 0.540 & 0.550 & 0.580 \\
$\mathrm{HC}$ & 51 & 52 & 51 & 53 \\
Nox & 23 & 24 & 22 & 24 \\
\hline
\end{tabular}



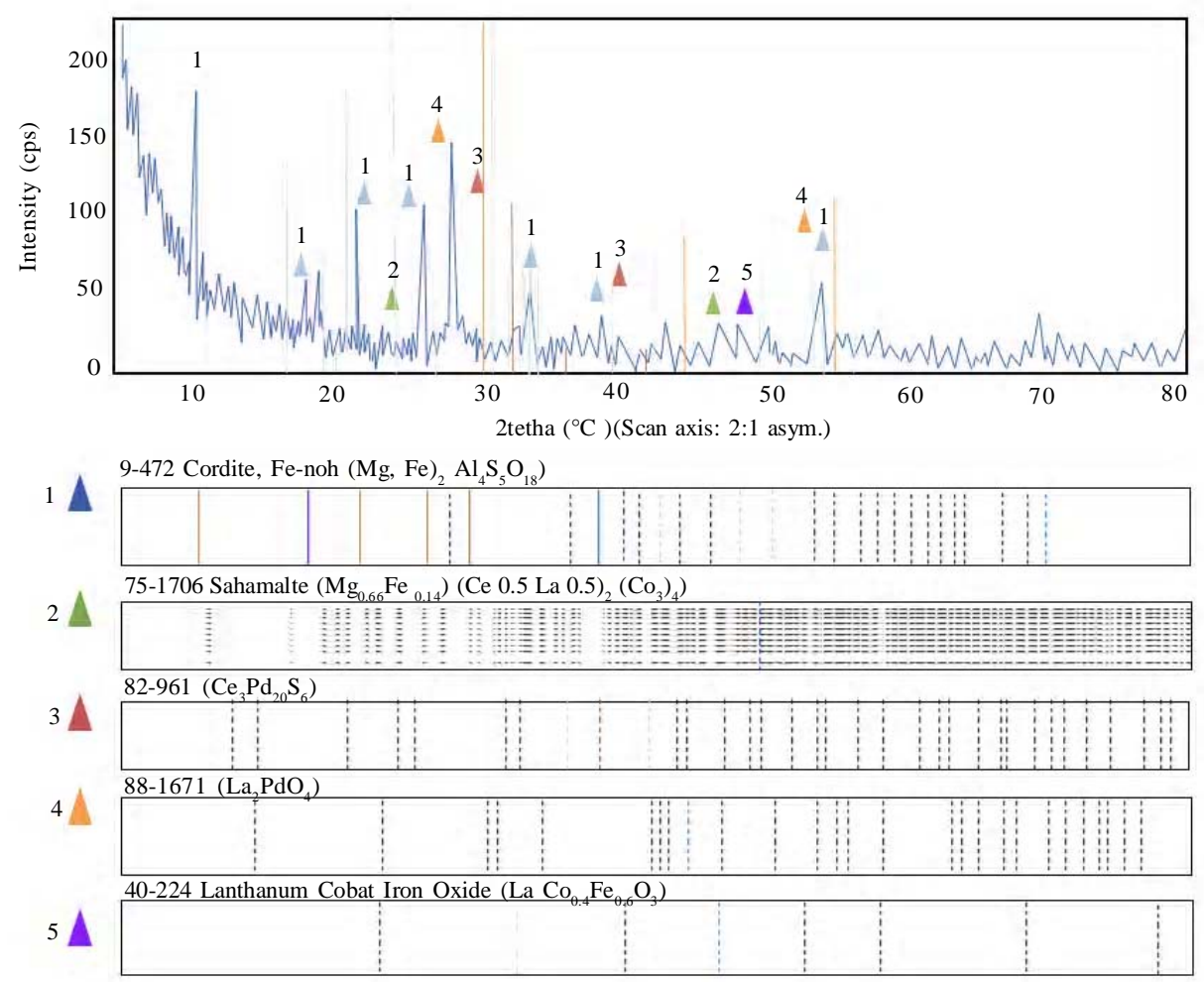

Fig. 1: XRD profiles of prepared catalyst that calcined at $760{ }^{\circ} \mathrm{C}$ for $3 \mathrm{~h}$

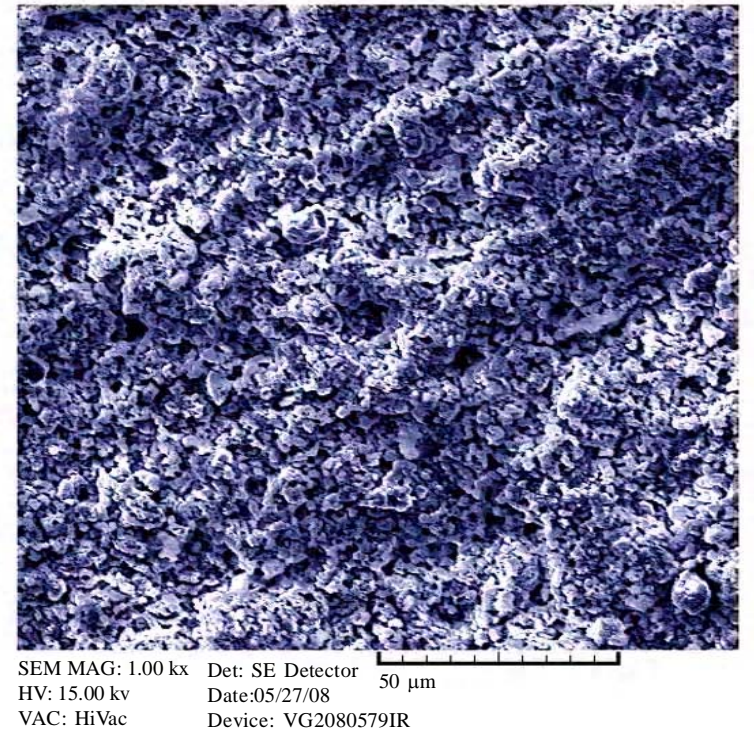

Fig. 2: SEM micrographs of the catalysts prepared by citrate method (La-Ce) (Fe,Co,Pd) $\mathrm{O}_{3}$ and calcined at 760 ${ }^{\circ} \mathrm{C}$ for $3 \mathrm{~h}$

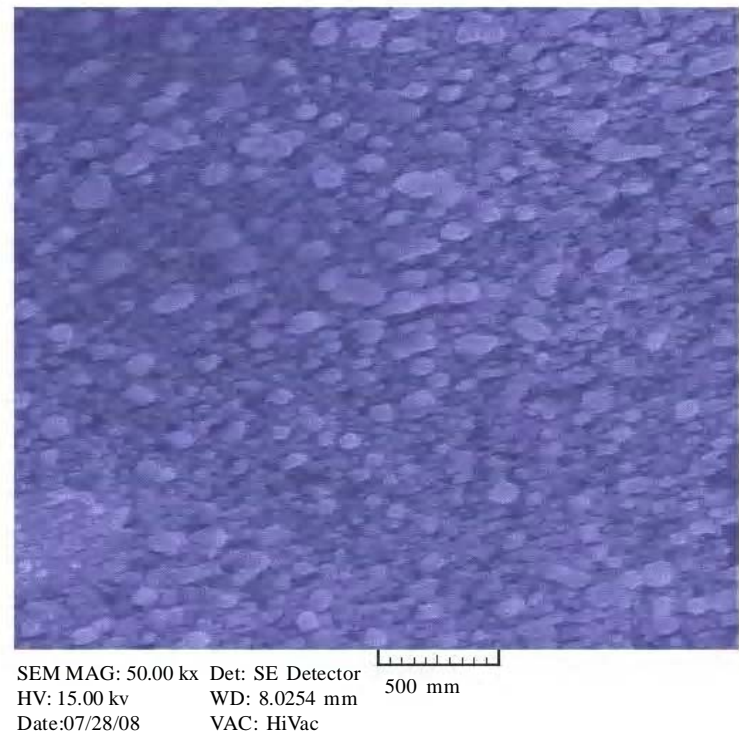

Fig. 3: SEM micrographs of the catalyst coat prepared by citrate method (La-Ce)(Fe,Co,Pd) $\mathrm{O}_{3}$, calcined at $760{ }^{\circ} \mathrm{C}$ for $3 \mathrm{~h}$ 
Int. J. Environ. Sci. Tech., 6 (1), 105-112, Winter 2009

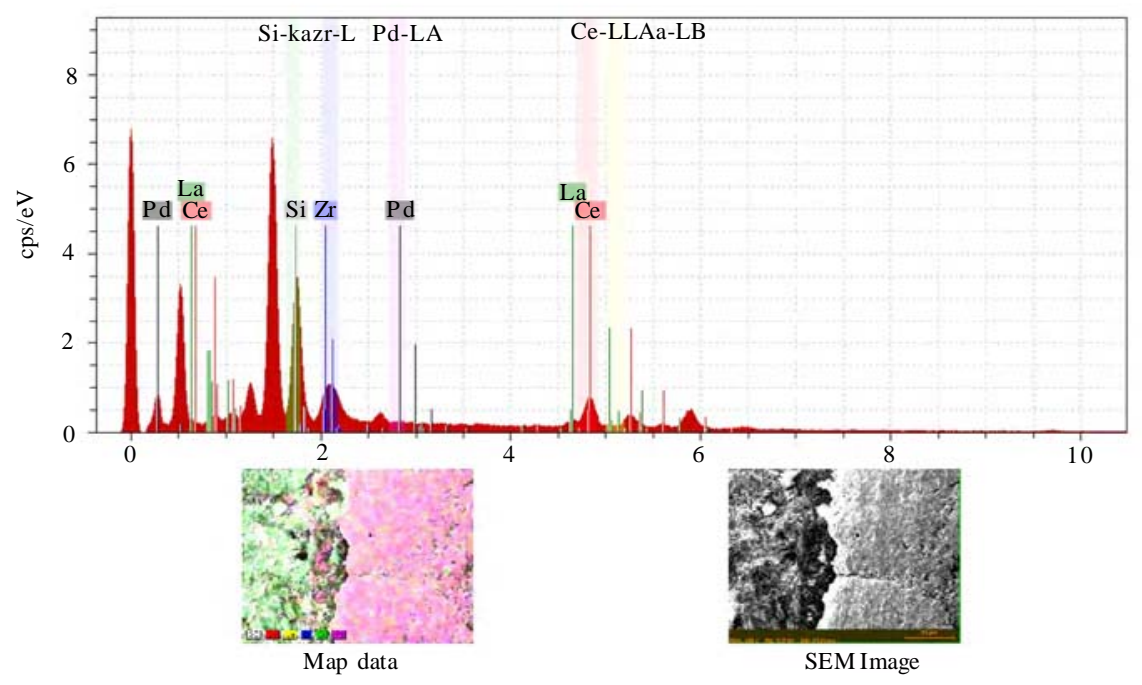

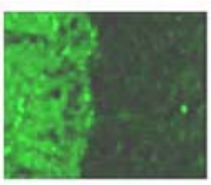

Si-KA

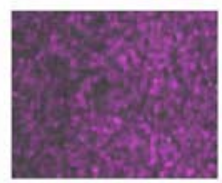

Pd-LA

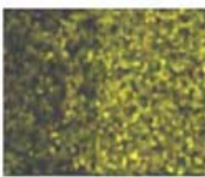

La-LB

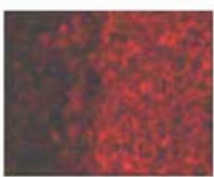

Ce-LA

Fig. 4: Map of the coat
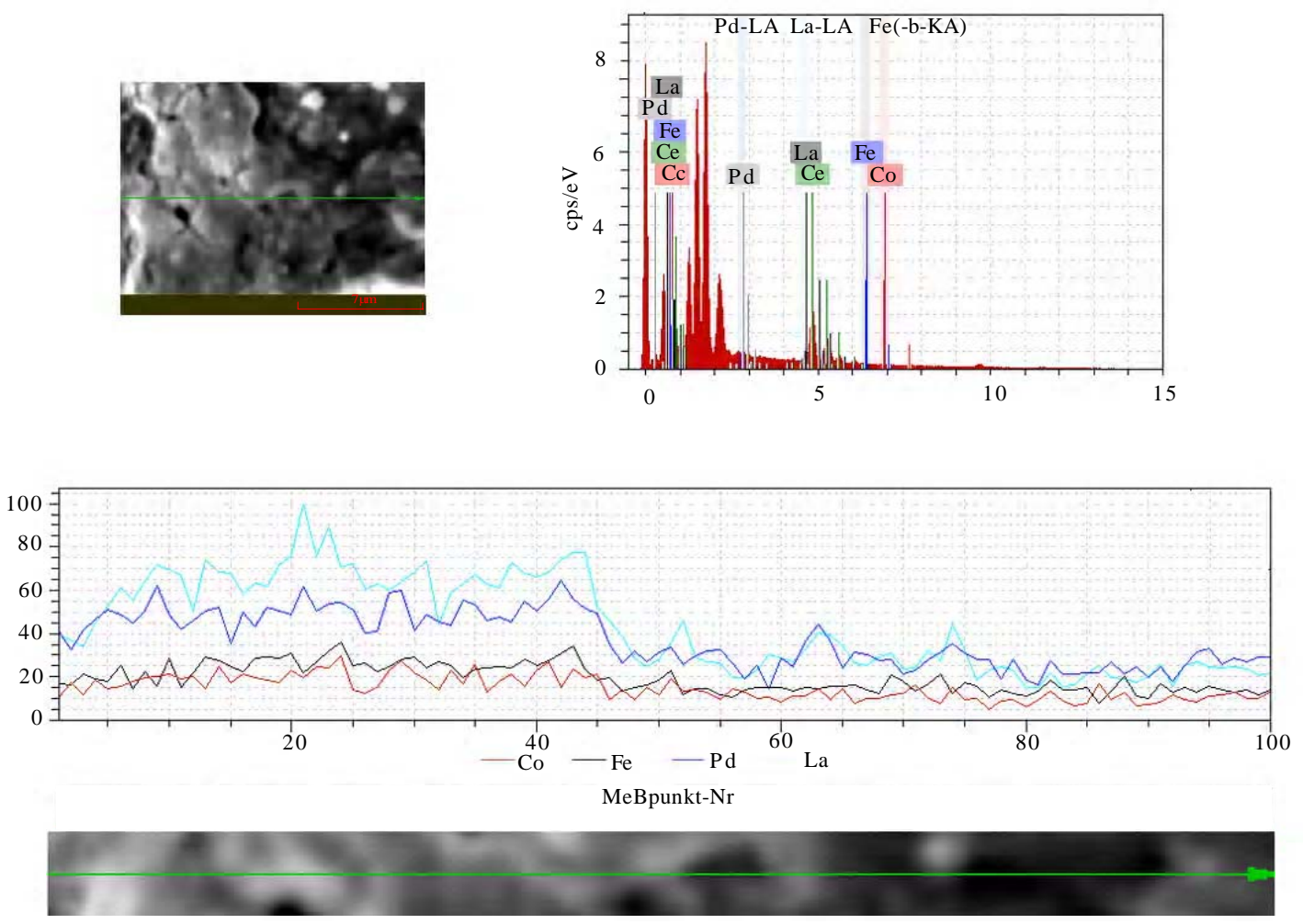

Fig. 5: Line scan of the coat 

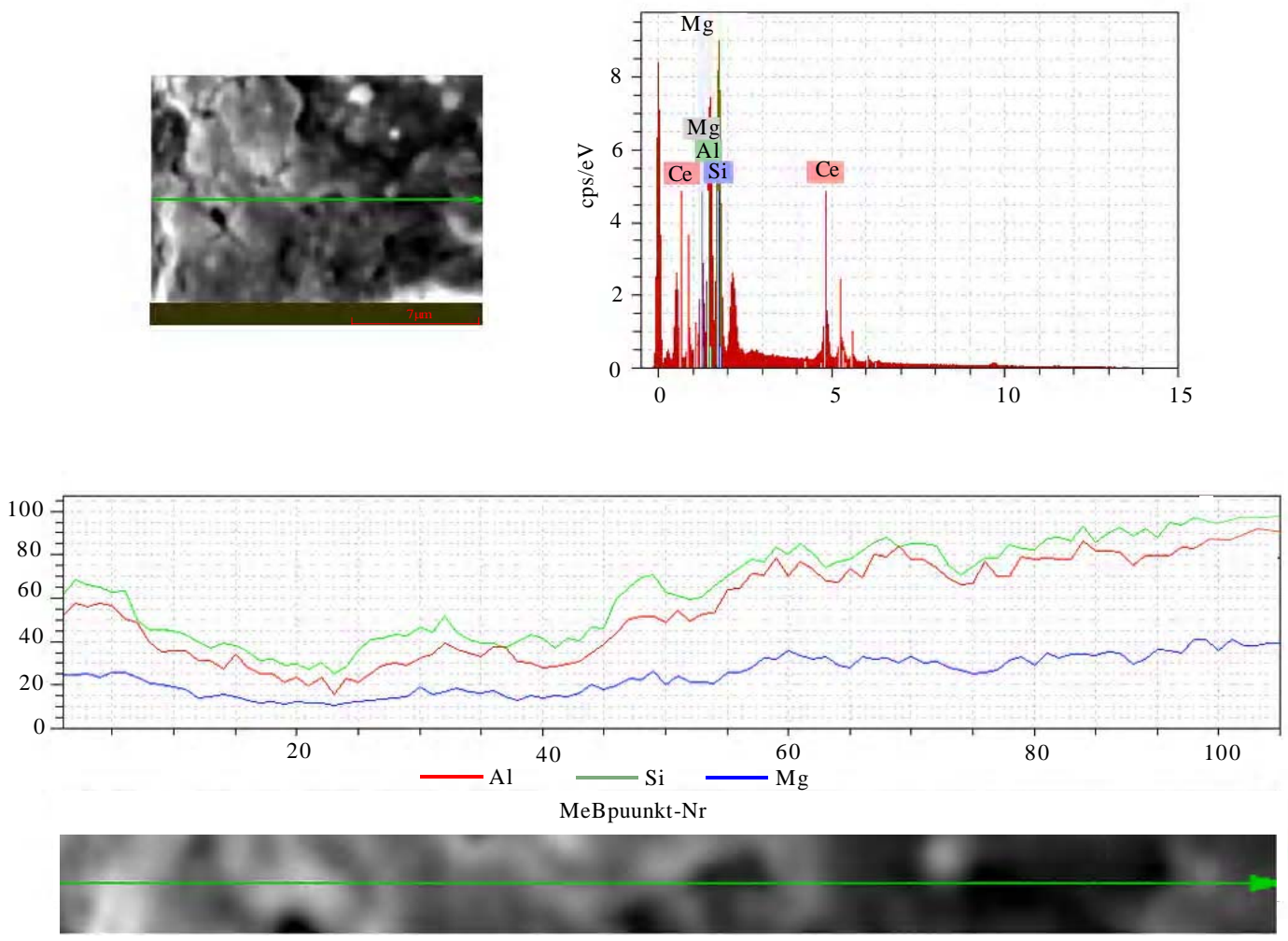

Fig. 6: Line scan of the coat

of (La-Ce)(Fe,Co,Pd)O $\mathrm{O}_{3}$ calcined at $760^{\circ} \mathrm{C}$ illustrated the interface between coat and base.

It was clear that there was a strong stick between cordierite base and coat substance. Fluctuations in line scan indicated reactions between coat materials and base.

In accordance with map and line scan, X-ray diffraction shows [((Mg, Fe $\left.\left.)_{2} \mathrm{Al}_{4} \mathrm{Si}_{5} \mathrm{O}_{18}\right)\right],\left(\mathrm{Ce}_{3} \mathrm{Pd}_{20} \mathrm{Si}_{6}\right)$ and $\left[\left(\left(\mathrm{Mg}_{0.86} \mathrm{Fe}_{0.14}\right)\left(\mathrm{Ce}_{0.5} \mathrm{La}_{0.5}\right)_{2}\left(\mathrm{CO}_{3}\right)_{4}\right)\right]$ phase between coat materials and base too.

\section{CONCLUSION}

The prepared ( $\mathrm{La}-\mathrm{Ce})(\mathrm{Fe}, \mathrm{Co}, \mathrm{Pd}) \mathrm{O}_{3}$ samples exhibited good activities as regular noble metal catalysts with the highest conversion.

Pd-based materials are well known highly active catalysts for a wide range of heterogeneous reactions from fine chemical synthesis (Blaser et al., 2001) to partial or full oxidation reactions (Ciuparu et al., 2002; Centi and Mol., 2001; Gelin and Primet, 2002). Partial reduction of the Pd containing catalyst for a proper duration of time significantly enhances the oxidation activity of the catalyst due to segregation of Pd from the perovskite lattice and its dispersion on the catalyst surface as metallic nanoparticles.

The catalyst was applied on Rd cars and the amount of emission was measured with vehicle emission test systems (AVL) at Sapco company and compared by imported catalyst of Iran Khodro. It can be concluded that Perovskite catalyst reduces emission better than imported catalysts of Iran Khodro company with lower emission and price.

\section{ACKNOWLEDGEMENTS}

The support from the Sapco Company of Iran Khodro and Science and Research Branch, IAU, on research project is gratefully acknowledged.

\section{REFERENCES}

Beck, D. D.; Sommers, J. W.; DiMaggio, C. L., (1997). Axial characterization of catalytic activity in close-coupled lightoff and underfloor catalytic converters., Appl. Catal. B-Environ., 11 (3-4), 257-272.

Bi, Z.;Cheng, M.; Dong, Y.; Wu, H.; She, Y.; Yi, B., (2005). Electrochemical evaluation of $\mathrm{La}_{0.6} \mathrm{Sr}_{0.4} \mathrm{CoO}_{3}-\mathrm{La}_{0.45} \mathrm{Ce}_{0.55} \mathrm{O}_{2}$ composite cathodes for anode-supported $\mathrm{La}_{0.45} \mathrm{Ce}_{0.55} \mathrm{O}_{2}-$ 
La0.9Sr0.1Ga0.8Mg0.2O2.85 bilayer electrolyte solid oxide fuel cells., Solid State Ionics, 176 (7-8), 655-661.

Blaser, H. U.; Indolese, A.; Schnyder, A.; Steiner, H.; Studer, M., (2001). Supported palladium catalysts for fine chemicals synthesis., Catal. A Chem., 173(1-2), 3-18.

Brosha, E. L.; Mukundan, R.; Brown, D. R.; Garzon, F. H.; Visser, J. H.; Zanini, M.; Zhou, Z.; Logothetis, E. M., (2000). CO/HC sensors based on thin films of $\mathrm{LaCoO} 3$ and La0.8Sr0.2CoO3" $\delta$ metal oxides, Sensors Actuat. B-Chem., 69 (1) 171-182.

Centi, G.; Mol, J., (2001). Supported palladium catalysts in environmental catalytic technologies for gaseous emissions., J. Mol. Catal. A-Chem. 173 (1-2), 287-312.

Cimino, S.; Landi, G.; Lisi, L.; Russo, G., (2006). Rh-La ( $\mathrm{Mn}, \mathrm{Co}) \mathrm{O} 3$ monolithic catalysts for the combustion of methane under fuel-rich conditions., Catal. Today., 117 (4), 454-461

Ciuparu, D.; Lyubovsky, M. R.; Altman, E.; Pfefferle, L. D.; Datye, A., (2002). catalytic combustion of methane over Palladium-based cataysts., catal. Rev. Sci. Eng., (44) 4, 593-649.

Engelmann Pirez, M.; Granger, P.; Leclercq, G., (2005). Investigation of the catalytic performances of supported noble metal based catalysts in the $\mathrm{NO}+\mathrm{H} 2$ reaction under lean conditions., Catal. Today, 107-8, 315-322.

Gelin, P.; Primet, M., (2002). Complete oxidation of methane at low temperature over noble metal catalysts: A review, Appl. Catal. B-Environ., 39 (1), 1-37.

Goldwasser, M. R.; Rivas, M. E.; Lugo, M. L.; Pietri, E.; Pérez-Zurita, J.; Cubeiro, M. L.; Griboval Constant, A.; Leclercq, G., (2005). Combined methane reforming in presence of $\mathrm{CO} 2$ and $\mathrm{O} 2$ over $\mathrm{LaFe} 1$-xCoxO3 mixed-oxide perovskites as catalysts precursors, Catal. Today, 107-8, 106-113.

Hansteen, O. H.; Fjellvag, H.; Hauback, B. C., (1998). Crystal structure, thermal and magnetic properties of La3Co3O8. Phase relations for LaCoO3- $\delta(0.00<\delta<0.50)$ at $673 \mathrm{~K}$., J. Mater Chem., 8 (9), 2081-2088.

Heck, R. M.; Farrauto, R. J., (1995). Environmental catalysis into the 21st. century, Catalytic Air Pollution Control: Commercial Technology, Van Nostrand Reinhold, New York, pp. 95-102.

Holc, J.; Slunečko, J.; Hrovat, M., (1995). Temperature characteristics of electrical properties of (Ba,Sr) $\mathrm{TiO} 3$ thick film humidity sensors, Sensors Actuat. B-Chem., 26 (1-3), 99-102.

Huang, L.; Bassir, M.; Kaliaguine, S., (2005). Reducibility of $\mathrm{Co3}+$ in perovskite-type $\mathrm{LaCoO} 3$ and promotion of copper on the reduction of $\mathrm{Co} 3+$ in perovskite-type oxides., Appl. Surf. Sci., 243 (1-4), 362-377.

Kharton, V. V.; Yaremchenko, A. A.; Naumovich, E. N. (1999). Research on the electrochemistry of oxygen ion conductors in the former Soviet Union. II. Perovskiterelated oxides, J. Solid State Electr., 3 (6), 303-326.

Kong, L. B.; Shen, Y. S. (1996). Gas-sensing property and mechanism of CaxLa1-xFeO3 ceramics., Sensors Actuat. B-Chem., 30 (3), 217-221.

Leontiou, A. A.; Ladavos, A. K.; Pomonis, P. J., (2003). Catalytic NO reduction with $\mathrm{CO}$ on $\mathrm{La} 1$ "xSrx $(\mathrm{Fe} 3+/$ $\mathrm{Fe} 4+) \mathrm{O} 3 \pm \delta$ perovskite-type mixed oxides( $\mathrm{x}=0.00,0.15$,
$0.30,0.40,0.60,0.70,0.80$, and 0.90), J. Appl. Catal. AGeneral, 241 (1), 133-141.

Liu, Y.; Meng, M.; Yao, J. S.; Zha, Y. Q. (2007). Prilimary result of temperature distribution and associated thermal stress in crust in Tianshui, China., Acta Seismol. Sinica, 20 (6), 641-655.

Lukaszewicz, J. P.; Miura, N.; Yamazoe, N., (1990). A LaF3based oxygen sensor with perovskite-type oxide electrode operative at room temperature, Sensors Actuat. B-Chem., 1 (1-6), 195-198.

Mondragon Rodriguez, G. C.; Ochrombel, R.; Saruhan, B., (2008). Meta-stability and microstructure of the LaFe0.65Co0.3Pd0.05O3perovskite compound prepared by a modified citrate route, J. Eur. Ceram. Soc., 28 (13), 2611-2616.

Nakamura, T.; Petzow, G.; Gauckler, L.J., (1979). Stability of the perovskite phase $\mathrm{LaBO} 3(\mathrm{~B}=\mathrm{V}, \mathrm{Cr}, \mathrm{Mn}, \mathrm{Fe}, \mathrm{Co}, \mathrm{Ni}$ ) in reducing atmosphere I. Experimental results., Mater. Res. Bull. 14 (5), 649-659.

Nishihata, Y.; Mizuki, J.; Tanaka, H.; Uenishi, M.; Kimura, M., (2005). Self-regeneration of palladium-perovskite catalysts in modern automobiles, J. Phys. Chem. Solids, 66 (2-4), 274-282.

Rainer, D.R.; Koranne, M.; Vesecky, S.M.; Goodman, D.W.; (1997). CO + O2 and CO + NO Reactions over Pd/Al2O3 Catalysts, J. Phys. Chem. B., 101 (50), 10769-10774.

Royer, S.; Bérubé, F.; Kaliaguine, S., (2005a). Effect of the synthesis conditions on the redox and catalytic properties in oxidation reactions of LaCo1"xFexO3, Appl. Catal. AGeneral, 282 (1-2), 273-284.

Royer, S.; Duprez, D.; Kaliaguine, S., (2005b). Role of bulk and grain boundary oxygen mobility in the catalytic oxidation activity of LaCo1-xFexO3, J. Catal., 234 (2), 364-375.

Royer, S.; van Neste, A.; Davidson, R.; McIntyre, S.; Kaliaguine, S., (2004). Methane Oxidation over Nanocrystalline LaCo1-XFeXO3: Resistance to SO2 Poisoning., Ind. Eng. Chem. Res., 43 (18), 5670-5680.

Skinner, S. J., (2001). Recent advances in perovskite-type materials for SOFC cathodes., Fuel Cells Bull., 4 (33), 612 .

Szabo, V.; Bassir, M.; van Neste, A.; Kaliaguine, S., (2003). Perovskite-type oxides synthesized by reactive grinding: Part IV. Catalytic properties of LaCo1"xFexO3 in methane oxidation., Appl. Catal. B-Environ, 1 (20), 81-92.

Takamura, H.; Enomoto, K.; Aizumi, Y.; Kamegawa, A.; Okada, M., (2004). Preparation and oxygen permeability of Pr-Al-based perovskite-type oxides., Solid State Ionics, 175 (1-4), 379.

Tao, S. W.; Irvine, J. T. S., (2004). Catalytic Properties of the Perovskite Oxide La0.75Sr0.25Cr0.5Fe0.5O3- $\delta$ in Relation to Its Potential as a Solid Oxide Fuel Cell Anode Material., Chem. Mater., 16 (21), 4116.

Traversa, E.; Matsushima, S.; Okada, G.; Sadaoka, Y.; Sakai, Y.; Watanabe, (1995). NO2 sensitive LaFe3 thin films prepared by r. f. sputtering., Sensors Actuat. B-Chem., 25 (1), 661-664.

Uhlenbruck, S.; Tietz, F. (2004). High-temperature thermal expansion and conductivity of cobaltites: potentials for adaptation of the thermal expansion to the demands for 
solid oxide fuel cells., Mater. Sci. Eng. B-Sold., 107 (3), 277-282.

Van Yperen, R.; Linder, D.; Mussmann, L.; Lox, E. S.; Kreuzer,

T., (1998). Catalysis and automotive pollution control IV, Stud. Surf. Sci. Catal., (116), 51-60.
Zhuyi, W.; Cheng, C.; Caihui, F.; Jinxing, W.; Zou, B.; Meng Z. J.; Fengqing W., (2008). Synthesis, Characterization and Humidity SensitiveProperties of Nanocrystalline LaCoxFe1"xO3., Acta Phys. Chim. Sin., 24 (3), 375-378.

\section{AUTHOR (S) BIOSKETCHES}

Khanfekr, A., M.Sc. student, Department of Metallurgy and Materials Engineering, Science and Research Branch, Islamic Azad University, Tehran, Iran. Email: arsia_khan@yahoo.com

Arzani, K., Ph.D., Department of Metallurgy and Materials Engineering, Science and Research Branch, Islamic Azad University, Tehran, Iran. Email: dr_kaveh_arzani@yahoo.com

Nemati, A., Ph.D., Sharif University of Technolgy, Tehran, Iran. Email: nemati@sharif.edu

Hosseini, M., Ph.D., Materials Science and Engineering research of Sapco Company, Iran Khodro Company, Tehran, Iran. Email: mahossaini@sapco.com

\section{This article should be referenced as follows:}

Khanfekr, A.; Arzani, K.; Nemati, A.; Hosseini, M., (2008). Production of perovskite catalysts on ceramic monoliths with nanoparticles for dual fuel system automobiles. Int. J. Environ. Sci. Tech., 6 (1), 105-112. 